\title{
Dental prenatal care in pregnancy
}

\section{Atenção integral na gestação: pré-natal odontológico}

\author{
Tânia Adas SALIBA ${ }^{1}$ iD 0000-0003-1327-2913 \\ Lia Borges de Mattos CUSTÓDIO² iD 0000-0002-1778-111X \\ Nemre Adas SALIBA ${ }^{3}$ iD 0000-0001-9608-1631 \\ Suzely Adas Saliba MOIMAZ3 ${ }^{3}$ 0000-0002-4949-529X
}

\section{ABSTRACT}

Objective: The aimed was to analyze health care protocols for pregnant women with a focus on oral health. Method: This is a crosssectional, descriptive, documental study on oral health conducted on health care protocols for pregnant women in 2019. Searches conducted in the internet identified maternal health protocols made publicly available by Brazilian municipalities and states. In this search, we considered the following keywords in the Portuguese language: "protocolo" (protocol), "guia" (guide), "linha-guia" (guideline), "diretrizes" (guidelines), "documento" (document) and "orientação" (guidance). It was consulted the following documents by the Brazilian Ministry of Health: National Oral Health Policy, Reception to spontaneous demand: most common complaints in basic care and Basic care protocols: women's health. The following variables were analyzed: the entry point of each pregnant woman in the health care system, their first dental appointment, the reference and the counter-reference system between the levels of care and the procedures performed by the dentist. Results: It was collected a total of 12 municipal protocols, 5 state and 8 international protocols. Most of these documents did not include all the variables analyzed and in national documents, the procedures reported presented a great disagreement and the reference and counter-reference system was little approached. Most of international documents presented a description of general gestation care, changes in women's period, and the need for prenatal dental care. Conclusions: It was observed that the "procedures indicated" was dimensions most contemplated. The referral and counter-reference system was not mentioned in all documents.

Indexing terms: Oral health. Pregnancy. Public health.

\section{RESUMO}

Objetivo: O objetivo foi realizar análise documental de protocolos de atenção à saúde bucal de gestantes. Método: Trata-se de um estudo transversal, descritivo realizado em 2019. Foram realizadas buscas na rede mundial de computadores pelos protocolos sobre saúde materna disponibilizados para acesso público por municípios e estados brasileiros. Foram consideras as seguintes palavras-chave na estratégia de busca: "protocolo", "guia", "linha-guia", "diretrizes" e "orientação". Na página do Ministério da Saúde, foram consultados os seguintes documentos: Política Nacional de Saúde Bucal, Acolhimento à demanda espontânea: queixas mais comuns na atenção básica e Protocolos de atenção básica: saúde das mulheres. Nos protocolos, foram analisadas as variáveis 
acesso aos serviços de saúde, estabelecimento da primeira consulta odontológica, descrição de procedimentos indicados e fluxograma para referência e contrarreferência. Resultados: Foram encontrados 12 protocolos municipais, 5 estaduais e 8 internacionais. Nos protocolos nacionais, a maioria não contempla todas as variáveis analisadas, nos procedimentos indicados há grande discordância e o sistema de referência e contrarreferência foi pouco abordado. Nos documentos internacionais a maioria aborda cuidados gerais sobre a atenção odontológica na gestação; alguns abordam a prescrição medicamentosa, forma e a importância do trabalho em equipe multiprofissional para o sucesso da iniciativa, práticas alimentares e problemas relacionados à carie dentária na gestação. Conclusões: Observou-se que a dimensão "tipos de procedimentos indicados" foi mais contemplada. As dimensões "acesso", "primeira consulta odontológica" e "referência e contrarreferência" não foram citadas em todos os protocolos.

Termos de indexação: Saúde bucal. Gravidez. Saúde pública.

\section{INTRODUCTION}

Maternal mortality is a public health problem, especially in developing countries [1]. It is such an important indicator for assessing the health conditions of a population that the analysis of causes and conditions of maternal mortality can indicate the degree of development of a given society. High Maternal Mortality Ratios (MMR) point out precarious socioeconomic conditions, low level of information and schooling, the presence of violence in family dynamics, and, above all, difficulties in accessing good quality health services [2].

In a United Nations (UN) meeting in 2000, 189 countries signed a commitment to combat extreme poverty and other ills in society to make the world more supportive and just, thus developing the millennium goals (Millennium Development Goals - MDG) [3,4]. The improvement of the health of pregnant women was among these goals, including the goal of reducing MMR in 75\% by 2015 [3,4]. In Brazil, between 1990 and 2015, MMR per 100,000 live births decreased from 104 to 44 deaths; although the goal was not reached, significant advances were achieved. Maternal and child health care was prioritized in a program established by the Ministry of Health, Pacto pela Saúde (Pact for Health) [5,6], and in the MDGs [3], but it is still a challenge for managers of the Brazilian health system. This health care system needs to be overcome, because it is fragmented and characterized by a hierarchical organization with a discontinuous care, focus on acute conditions, on-demand reactive action, and emphasis on curative and rehabilitative interventions [79]. With the aim to integrate health services, the Brazilian health care network system seeks to fill the existing gap in care [7-9] by promoting continuous and integral services and optimizing the management and costs of the services provided, due to a rational dynamics of the use of the resources [7-10]. In this context, the Ministry of Health created the Rede Cegonha (the Stork Network) in 2011
[11] to foster the implementation of a new health care model for the mother-child binomial, with a focus on childbirth, birth, growth, and child development from zero to 24 months of age. This project also aimed to organize the Rede de Atenção à Saúde Materna e Infantil (Maternal and Child Health Care Network) in order to guarantee access to health care, welcome and resolution and reduce maternal and child mortality [11].

Within the reproductive health care cycle, the antenatal care comprises important health care functions, including health promotion, screening, diagnosis and prevention of diseases [12]. Thus, dental antenatal cares are of great relevance for promoting maternal and child health [13-15], since pregnant women represent a risk group for oral diseases due to their physical, biological, hormonal and behavioral changes, and the high prevalence of dental caries and periodontal diseases in pregnancy [1622]. There are also indications that periodontal diseases may be associated with low-birth-weight newborns and preterm births $[23,24]$.

Dental care in gestation can promote healthy habits and facilitate breastfeeding, which leads to the best development and orofacial growth of the baby [25]. However, pregnant women and healthcare professionals have some resistance to perform dental procedures during pregnancy. Often for fear of harming babies, healthcare professionals end up not referring pregnant women to dental treatment, thus consolidating the myths and taboos about dental care during pregnancy [13]. Since oral health is inseparable from general health [26], providing integral, multiprofessional and transdisciplinary care to women's health is of utmost importance [27], including pediatricians, gynecologists, obstetricians, nurses, dentists and other health professionals. In this context, in order to ensure that pregnant women acquire healthy habits and that health education practices be effective, the multiprofessional team must have a unified discourse, thus avoiding controversial information and providing greater 
security to pregnant women in the health care provided in the gestation period.

The provision of individual and collective care guarantees universal access with fairness and integral care to life cycles and vulnerable groups [28]. Thus, even the size of the service network and the organization of work processes represent a challenge for health care management. The organization of the demand and the existence of protocols and guidelines are of real importance to guide the health care flow; however, there are few studies about protocols on health care to pregnant women, which ratifies the need for research to guarantee the improvement of the quality of care provided, the access to this care, and, consequently, the consolidation of the system. In this context, we aimed to analyze health care protocols for pregnant women with a focus on oral health.

\section{METHODS}

This is a cross-sectional, descriptive, documental study on oral health conducted on health care protocols for pregnant women in 2019. Searches conducted in the internet identified maternal health protocols made publicly available by Brazilian municipalities and states. In this search, we considered the following keywords in the Portuguese language: "protocolo" (protocol), "guia" (guide), "linha-guia" (guideline), "diretrizes" (guidelines), "documento" (document) and "orientação" (guidance). These terms were combined with descriptors related to oral health (dental caries, periodontal disease, oral health, dental radiography) and gestation (pregnancy, gestation, pregnancy). We included all public documents mentioning pregnant women's oral health. We also searched international protocols with an outcome in dental care for pregnant women in databases. Further, we verified bibliographic references mentioned in these protocols to obtain other protocols not indexed in the databases. We consulted the following documents by the Brazilian Ministry of Health: Política Nacional de Saúde Bucal (Bucal Health), Acolhimento à demanda espontânea: queixas mais comuns na atenção básica (Humanized reception of patients without an appointment: the most common complaints in spontaneous demand of basic attention), and Protocolos de atenção básica: saúde das mulheres (Protocols of Primary Care: Women's Health Care). We also searched the Cadernos de Saúde Bucal, a manual published by the Health Department of the state of São
Paulo. The following variables were analyzed: the entry point of each pregnant woman in the health care system, their first dental appointment, the reference and the counter-reference system between the levels of care and the procedures performed by the dentist.

\section{RESULTS}

We collected a total of 12 municipal protocols (Belo Horizonte, Colombo, Curitiba, Florianópolis, Fortaleza, Londrina, Natal, Porto Alegre, Praia Grande, Rio de Janeiro, São Bernardo do Campo, and São Paulo) and 5 state protocols (Paraná, Rio Grande do Sul, Minas Gerais, Espírito Santo, and Sergipe). Most of these documents did not include all the variables analyzed. The procedures reported presented a great disagreement, and the documents with the indication of the form of access showed free demand in consonance with active search; however, the reference and counter-reference system was little approached (table 1).

Our search in the databases returned eight international documents. Most of them presented a description of general gestation care, changes in women's period, and the need for prenatal dental care; some approached prescription drugs, form and the importance of multiprofessional teamwork for the success of dental care during pregnancy, feeding practices, and problems related to dental caries during pregnancy (table 2).

\section{DISCUSSION}

The present study on health care protocols for pregnant women with a focus on oral health found relevant information regarding the variables analyzed. The way pregnant women enter public health care services is extremely relevant for prevention, promotion and recovery of the mother-child binomial's health. Considering that late prenatal care can lead to complications for both mother and child, health teams should always be aware of community discourses that can help the population identify pregnancy in a timely manner, as well as to accommodate spontaneous demands (urgency and emergency) and start the prenatal care with the multiprofessional team [28]. The main means of accessing the health care system must be active search and not free demand, so that there is a timely opportunity to prevent injuries rather than just health recovery. 
Table 1. Classification of protocols according to access criteria, indication of first dental appointment, reference and counter-referral system, and indicated procedures performed by the dentist in pregnant women. 2019.

\begin{tabular}{|c|c|c|c|c|}
\hline Document & $\begin{array}{l}\text { Access from pregnant } \\
\text { woman on health system }\end{array}$ & $\begin{array}{l}\text { First Dental } \\
\text { appointment }\end{array}$ & $\begin{array}{l}\text { Dental Reference and } \\
\text { Counter-referral }\end{array}$ & $\begin{array}{l}\text { Procedures } \\
\text { indicated }\end{array}$ \\
\hline $\begin{array}{l}\text { Humanized reception of patients without an } \\
\text { appointment: the most common complaints } \\
\text { in spontaneous demand of basic attention }\end{array}$ & Free demand & No & $\begin{array}{l}\text { Yes } \\
\text { (Do not specify the } \\
\text { pregnant woman) }\end{array}$ & No \\
\hline $\begin{array}{l}\text { Protocols of Primary Care: Women's Health } \\
\text { Care }\end{array}$ & $\begin{array}{l}\text { Free demand } \\
\text { Active Search }\end{array}$ & Yes & No & No \\
\hline Oral Health & $\begin{array}{l}\text { Free demand } \\
\text { Active Search }\end{array}$ & Yes & Yes & $\begin{array}{l}\text { Restorative Treatment, Surgery, } \\
\text { Periodontics, Prevention, Rx Drug } \\
\text { prescription (consult Doctor) }\end{array}$ \\
\hline SES SP oral health notebooks: Endodontics & No & No & No & Endodontic treatment \\
\hline Oral health notebooks of SES SP: Periodontics & No & No & No & Periodontal therapy \\
\hline Oral health notebooks of SES SP: PNE & No & After first trimester & No & $\begin{array}{l}\text { Prophylaxis, Immediate Treatments } \\
\text { Rx }\end{array}$ \\
\hline $\begin{array}{c}\text { City } \\
\text { A }\end{array}$ & $\begin{array}{l}\text { Free demand } \\
\text { Active Search }\end{array}$ & $\begin{array}{l}\text { Routing should } \\
\text { be done at any } \\
\text { gestational age }\end{array}$ & No & $\begin{array}{l}\text { Rx (preferably in the } 2 \text { nd and } 3 r d \\
\text { trimester) Anesthetic (without } \\
\text { vasoconstrictor) }\end{array}$ \\
\hline $\begin{array}{l}\text { City } \\
\text { B }\end{array}$ & $\begin{array}{l}\text { Free demand } \\
\text { Active Search }\end{array}$ & $\begin{array}{l}\text { After registering on } \\
\text { SISPrenatal, }\end{array}$ & No & $\begin{array}{l}\text { Rx (with protection), Anesthetic } \\
\text { (without vasoconstrictor) }\end{array}$ \\
\hline $\begin{array}{c}\text { City } \\
\text { C }\end{array}$ & Active Search & No & No & $\begin{array}{l}\text { Rx, Anesthetic, Working position: } \\
\text { lateral decubitus }\end{array}$ \\
\hline $\begin{array}{l}\text { City } \\
\text { D }\end{array}$ & Free demand & $\begin{array}{l}1 \text { appointment on } \\
\text { Prenatal and } \\
1 \text { in the } \\
\text { puerperium }\end{array}$ & No & $\begin{array}{l}\text { Restorative treatment, Surgery, } \\
\text { Periodontics, Prevention, Drug } \\
\text { Prescription }\end{array}$ \\
\hline $\begin{array}{l}\text { City } \\
\text { E }\end{array}$ & $\begin{array}{l}\text { Free demand } \\
\text { Active Search }\end{array}$ & $\begin{array}{l}\text { Schedule after 1st } \\
\text { ultrasonography }\end{array}$ & No & $\begin{array}{l}\text { Restorative treatment, Surgery } \\
\text { Periodontics, Prevention, Urgencies }\end{array}$ \\
\hline $\begin{array}{l}\text { City } \\
\text { F }\end{array}$ & $\begin{array}{l}\text { Free demand } \\
\text { Active Search }\end{array}$ & No & No & $\begin{array}{l}\text { Restorative treatment, Surgery, } \\
\text { Periodontics, Prevention, Urgencies } \\
\text { Local Anesthetics }\end{array}$ \\
\hline $\begin{array}{l}\text { City } \\
\text { G }\end{array}$ & $\begin{array}{c}\text { Free demand } \\
\text { Community Active Search } \\
\text { equipments }\end{array}$ & Yes & Yes & $\begin{array}{l}\text { Restorative Treatment, Prevention, } \\
\text { Drug prescription }\end{array}$ \\
\hline $\begin{array}{c}\text { City } \\
\text { H }\end{array}$ & $\begin{array}{l}\text { Free demand } \\
\text { Active Search }\end{array}$ & No & No & No \\
\hline City & $\begin{array}{l}\text { Free demand } \\
\text { Active Search }\end{array}$ & Yes & Yes & $\begin{array}{l}\text { Restorative treatment, Surgery, } \\
\text { Periodontics, Prevention, Rx, } \\
\text { Drug Prescription }\end{array}$ \\
\hline $\begin{array}{c}\text { City } \\
\text { J }\end{array}$ & $\begin{array}{l}\text { Free demand } \\
\text { Active Search }\end{array}$ & $\begin{array}{c}\text { Nurse should } \\
\text { evaluate the need } \\
\text { for dental surgeon } \\
\text { appointment }\end{array}$ & No & No \\
\hline $\begin{array}{l}\text { City } \\
\text { K }\end{array}$ & $\begin{array}{l}\text { Free demand } \\
\text { Active Search }\end{array}$ & Yes & No & No \\
\hline City & $\begin{array}{l}\text { Free demand } \\
\text { Active Search }\end{array}$ & $\begin{array}{l}\text { Health } \\
\text { professionals must } \\
\text { scheduled the } \\
\text { dental surgeon } \\
\text { appointment }\end{array}$ & No & $\begin{array}{l}\text { Risk classification for caries and } \\
\text { periodontal disease; Restorative } \\
\text { treatment, Surgery } \\
\text { Periodontics, prevention, Rx, } \\
\text { Medication Prescription }\end{array}$ \\
\hline
\end{tabular}


Table 1. Classification of protocols according to access criteria, indication of first dental appointment, reference and counter-referral system, and indicated procedures performed by the dentist in pregnant women. 2019.

\begin{tabular}{|c|c|c|c|c|}
\hline Document & $\begin{array}{l}\text { Access from pregnant } \\
\text { woman to the system }\end{array}$ & $\begin{array}{l}\text { First Dental } \\
\text { appointment }\end{array}$ & $\begin{array}{c}\text { Dental Reference and } \\
\text { Counter-referral }\end{array}$ & $\begin{array}{l}\text { Procedures } \\
\text { indicated }\end{array}$ \\
\hline $\begin{array}{c}\text { State } \\
\text { A }\end{array}$ & Active Search & $\begin{array}{l}\text { At the first } \\
\text { appointment, the } \\
\text { pregnant woman } \\
\text { must be attended / } \\
\text { scheduled with the } \\
\text { dental surgeon. }\end{array}$ & Yes & $\begin{array}{c}\text { Adequacy of buccal medium, } \\
\text { plaque control, periodontal } \\
\text { treatment }\end{array}$ \\
\hline $\begin{array}{l}\text { State } \\
\text { E }\end{array}$ & $\begin{array}{l}\text { Free demand } \\
\text { Active Search }\end{array}$ & Not included & No & No \\
\hline
\end{tabular}

Table 2. Main approaches of international protocols of dental care to pregnant women. 2019.

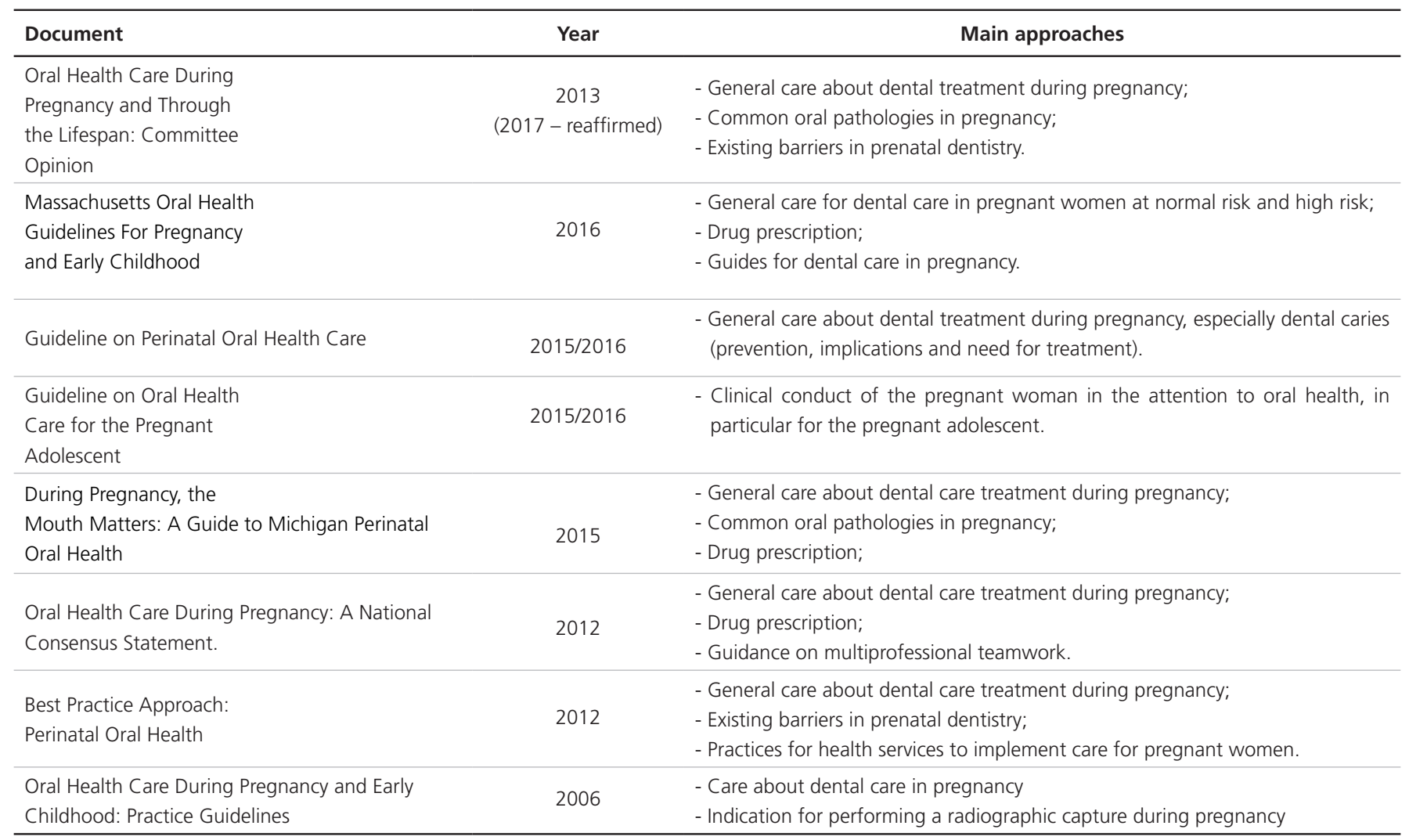


Another important factor mentioned in the documents is monitoring pregnant women to guarantee a continuous care and a reduction in maternal and child morbidity and mortality. Specialized health care centers agree with organizing the reference and counter-reference system according to levels of care. However, in dentistry, this scenario is not so clear. Agreements to organize care rarely occur. This impairs flow organization, slows the treatment course, and increases the possibility of causing damage to patients. Thus, protocols must always include objective criteria to forward pregnant women for medium and high-complexity treatments, as well as the centers that are reference and the criteria for the counter-reference. Protocols should also point out how to refer a patient through a form template, either on paper or through electronic systems, to standardize professionals' conducts. In accordance with the Ministry of Health's guidelines [29], the indication for dental appointment is performed by both the medical team and the nursing team, and the registration of pregnant women in the Sisprenatal system or their first prenatal visit are timely opportunities for an appointment with a dental surgeon. Pregnant women must always follow this schedule regardless of complaints about their oral health, since some oral pathologies have high prevalence during pregnancy, and the perception of need for help is very subjective. However, it is still a common practice to refer pregnant women to the dental surgeon only after their complaint. There is also very little monitoring of this referral by the multiprofessional team. Indication and monitoring of the patient in the dental treatment is of extreme importance for adherence to treatment.

Considering that there are many myths and taboos about dental care in gestation and that there is a gap in professional training that consolidates those myths, the indication of procedures and even prescriptions by the dental surgeon become controversial subjects. As a consequence of the changes that occur in gestation, the prevalence of oral pathologies such as caries and periodontal disease is high. Nausea and vomiting are associated with a high prevalence of caries during pregnancy $[16,18,19]$. In the third trimester, mainly, pregnant women present a decrease in their stomach's physiological capacity, and they reduce their food intake, but they eat more frequently. When associated with poor oral hygiene, these factors increase the risk of dental caries. Thus, the care and dietary guidance provided by the health team can promote a reduction in the consumption of sugary foods and carbohydrates and minimize the onset of oral diseases not only in the mother but also in the child. Although protocols diverge regarding the procedures to which pregnant women can be submitted, both restorative and endodontic treatments are indicated when the carious lesion is already compromised [30,31]. Regarding the development of periodontal diseases, pregnancy is not a determinant condition, but it increases the gingival response and modifies the clinical picture in pregnant women who already lack plaque control. Thus, alterations in the subgingival plaque composition, the immune response of pregnant women, and the concentration of sex hormones are factors that influence the periodontal response in the development of periodontal diseases $[13,22,32]$.

Some protocols indicate radiography preferably in the second and third trimesters; in emergency cases though, no contraindication is made for this type of examination in the first trimester. Other protocols indicated radiography without determining the gestation period. Studies have demonstrated that dental radiography is safe throughout pregnancy and should be indicated when necessary and performed with adequate maternal and fetus protection, with the help of a lead apron $[33,34]$. In 2016, Kelaranta demonstrated that the unprotected fetal dose was less than $1 \%$ of the annual dose limit of $1 \mathrm{mSv}$ [33], whereas evidence has shown that the amount of radiation absorbed (safe dose) should not exceed 5 rads. In this sense, in each dental radiography to which the mother is submitted, the fetus receives only 0.01 millirad; therefore, 500,000 radiographies would be necessary for the baby to receive 5 rads $[33,34]$.

Drug prescription during pregnancy should always take into account the risk/benefit based on maternalfetal morbidity and mortality, with reliance on drugs with a well-documented history of efficacy and safety, avoiding inappropriately investigated new drugs [13]. For pain control, analgesics known as acetaminophen (FDA Classification B) are considered the best indication for orofacial pain during pregnancy; they are the first choice for mild and moderate pain throughout the gestation period $[13,35,36]$. The second option of analgesics prescribed by health professionals is sodium dipyrone; however, its use is associated with agranulocytosis, that is, a reduction in the number of granulocytes in the peripheral blood (neutropenia), which may predispose infections. Non-steroidal anti-inflammatory drugs (NSAIDs) are contraindicated during the gestation period, because they cross the placental barrier. A high dose or the chronic use 
of such drugs near the end of gestation may also prolong labor, since prostaglandins, related to uterine contraction, are inhibited by NSAIDs. These anti-inflammatory drugs are still associated with the premature closure of the fetal ductus arteriosus, pulmonary arterial hypertension, and persistent pulmonary hypertension syndrome in the newborn $[13,36]$.

The use of anesthetics is controversial in the protocols. Some indicate anesthetics without a vasoconstrictor component for all pregnant women; however, studies have shown that, if there is no systemic contraindication, anesthetics with a vasoconstrictor increase the working time and then promote greater patient comfort and reduce the dose and toxicity $[13,37]$. Anesthetics without a vasoconstrictor component have a rapid absorption, so higher doses are necessary; consequently, its concentration will be high for both the mother and the fetus and will cause unnecessary stress due to recurrent reapplications [37]. Systemic conditions to which pregnant women may be subject to indicate the use of anesthetics without a vasoconstrictor, but the dental surgeon should be aware of the anesthetic's shorter time of effectiveness when performing the procedure. Thus, the anesthetic solution $2 \%$ lidocaine with adrenaline 1 : 100000 or noradrenaline 1: 50.000 is indicated as first choice for pregnant women. However, procedures that require a longer effective time than the lidocaine's can be performed with mepivacaine (Category C - FDA), but the use of felipressin as a vasoconstrictor is contraindicated, because it presents a risk of uterine contraction $[13,35,37]$.

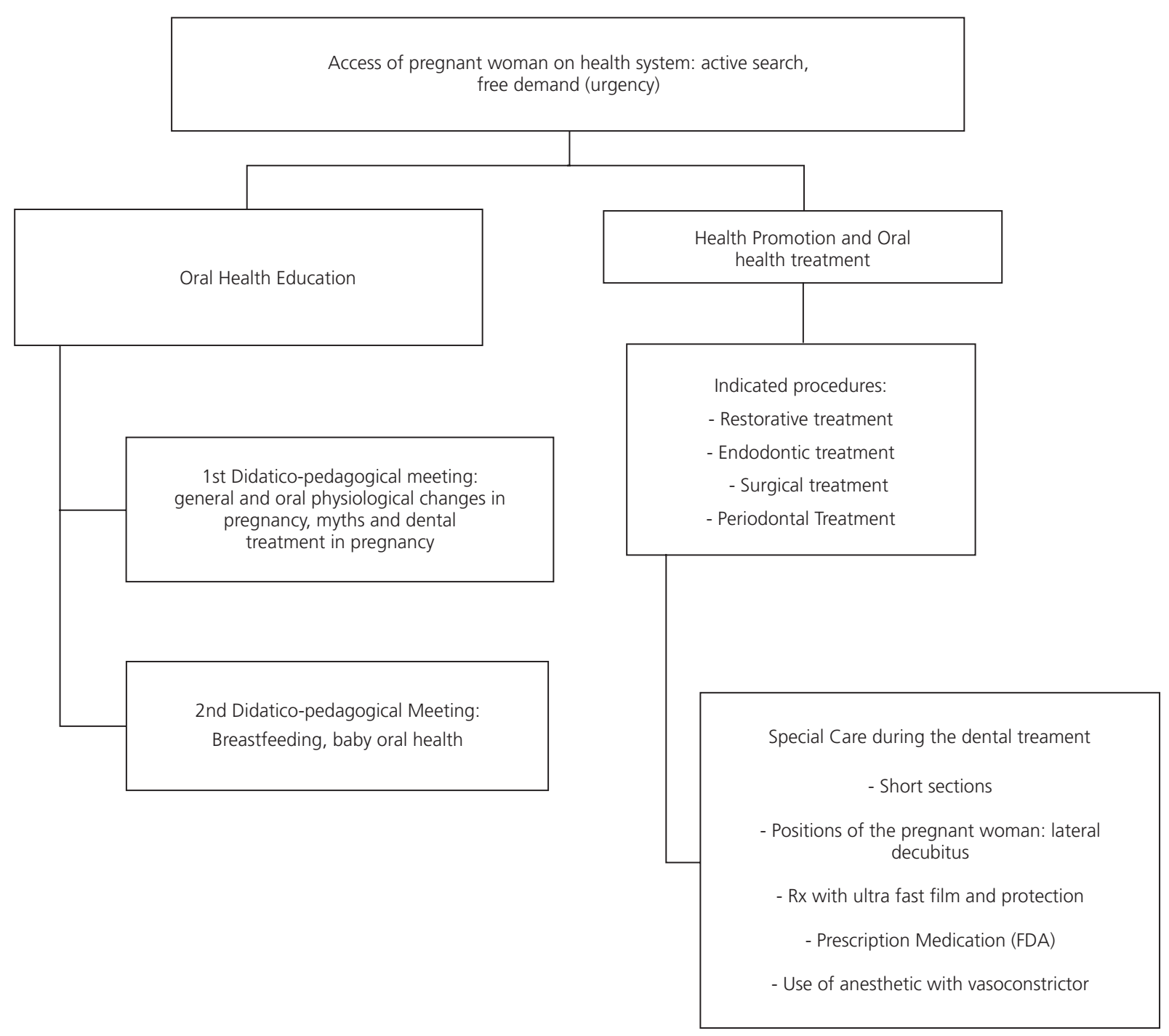

Figure 1. Flow of dental care of pregnant women. 2019. 
Prenatal follow-up is fundamental for the health of mother and child; however, health services have not always defined the routines that professionals should follow in their organizational structure. In order to improve the provision of health services, we developed a proposal to guide the flow of pregnant women to dental care (figure 1). When entering prenatal care, pregnant women must attend a pedagogical didactic meeting in order to clear doubts about dental treatment during pregnancy. They will be informed about the procedures they can be submitted to and the practices of prevention, promotion and recovery of health, always respecting the particularities of this approach, such as time and work position or adequate drug prescription. At the end, pregnant women should be guided in a pedagogical didactic meeting by the multiprofessional team on the subject of breastfeeding and baby oral health by means of a transdisciplinary approach on these themes, with the aim to strengthen the acquisition of healthy habits for both mother and child.

\section{CONCLUSION}

The dimension "types of procedures indicated" was the most contemplated. However, the dimensions "access" and "first dental appointment" were not mentioned in all protocols, which requires improvement. The mechanisms of "reference" and "counter-reference" regarding the levels of care also need to be improved by inserting pregnant women into specialized treatments.

\section{Collaborators}

TA SALIBA, conception and design of the study, drafting the article or revising it critically for important intellectual content and final approval of the version to be submitted. LBM CUSTODIO, acquisition of data, analysis and interpretation of data, drafting the article or revising it critically for important intellectual content and final approval of the version to be submitted. NA analysis and interpretation of data, and drafting the article and revising it critically for important intellectual content. SAS MOIMAZ, conception and design of the study, acquisition of data, analysis and interpretation of data, drafting the article or revising it critically for important intellectual content and final approval of the version to be submitted

\section{REFERENCES}

1. Morse ML, Fonseca SC, Barbosa MD, Calil MB, Eyer FPC. Maternal mortality in Brazil: what has the scientific literature shown in the last 30 years? Cad Saúde Pública. 2011;27(4):623-638. https://doi.org/10.1590/S0102-311X 2011000400002

2. Brasil. Ministério da Saúde. Secretaria de Atenção à Saúde. Departamento de Ações Programáticas. Política Nacional de Atenção Integral à Saúde da Mulher: princípios e diretrizes. Brasília: Ministério da Saúde; 2011 [citado 2018 Jul 17]. Disponível em: <http://bvsms.saude.gov.br/bvs/publicacoes/ politica_nacional_mulher_principios_diretrizes.pdf>.

3. World Health Organization, UNICEF, UNFPA, World Bank Group. Trends in maternal mortality: 1990 to 2015: estimates by WHO, UNICEF, UNFPA, World Bank Group and the United Nations Population Division. Genova: WHO; 2015 [citado 2018 Jul 17]. Disponível em: <https://www.who. int/reproductivehealth/publications/monitoring/maternalmortality-2015/en/>.

4. The World Bank. Millennium development goals. Washington: The World Bank; 2002 [citado 2018 Jul 17] Disponível em: <http://documents.worldbank.org/curated/ en/868641468766498894/pdf/multiOpage.pdf>.

5. Brasil. Ministério da Saúde. Secretaria Executiva. Departamento de Apoio à Descentralização. Coordenação-Geral de Apoio à Gestão Descentralizada. Diretrizes operacionais pactos pela vida, em defesa do SUS e de gestão. Brasília: Ministério da Saúde; 2006 [citado 2018 Jul 17]. Disponível em: <http:// www.saude.mppr.mp.br/arquivos/File/volume1.pdf>.

6. Brasil. Ministério da Saúde. Portaria n 399, de 22 de fevereiro de 2006. Divulga o Pacto pela Saúde 2006 - Consolidação do SUS e aprova as Diretrizes Operacionais do Referido Pacto. [citado 2018 Jul 17]. Disponível em: <http://bvsms.saude.gov. br/bvs/saudelegis/gm/2006/prt0399_22_02_2006.html>.

7. Mendes EV. A modelagem das redes de atenção à saúde. Belo Horizonte: Secretária de Estado de Saúde de Minas Gerais; 2007 [citado 2018 Jul 17]. Disponível em: <https://www. nescon.medicina.ufmg.br/biblioteca/imagem/0260.pdf>.

8. Mendes EV. A construção social da atenção primária à saúde. Brasília: Conselho Nacional de Secretários de Saúde; 2015 [citado 2018 Jul 17]. Disponível em: <http://www.saude. go.gov.br/wp-content/uploads/2016/12/a-construcao-socialda-atencao-primaria-a-saude.pdf>

9. Mendes EV. As redes de atenção à saúde. Brasília: Organização Pan-Americana da Saúde; 2011 [citado 2018 Jul 17]. Disponível em: <http://bvsms.saude.gov.br/bvs/publicacoes/ redes_de_atencao_saude.pdf>.

10. Silva SF. Organização de redes regionalizadas e integradas de atenção à saúde: desafios do Sistema Único de Saúde (Brasil). Ciênc Saúde Coletiva. 2011;16(6):2753-2762. https://doi. org/10.1590/S1413-81232011000600014

11. Brasil. Ministério da Saúde. Portaria n 1.459, de 24 de junho de 2011. Institui, no âmbito do Sistema Único de Saúde SUS - a Rede Cegonha. [citado 2018 Jul 17]. Disponível em: <http://bvsms.saude.gov.br/bvs/saudelegis/gm/2011/prt14 59_24_06_2011.html>.

12. Organização Mundial da Saúde. Recomendações da OMS sobre cuidados pré-natais para uma experiência positiva na gravidez. 2016. [citado 2018 Jul 17]. Disponível em: <https:// 
apps.who.int/iris/bitstream/handle/10665/250800/WHORHR-16.12-por.pdf?sequence=2>.

13. Moimaz SAS, Saliba NA, Garbin CAS. Odontologia para gestante: guia para o profissional da saúde. Araçatuba: UNESP; 2009.

14. Vamos CA, Thompson EL, Avendano M, Daley EM, Quinonez $R B$, Boggess $K$. Oral health promotion interventions during pregnancy: a systematic review. Community Dent Oral Epidemiol. 2015;43(5):385-396. https://doi.org/10.1111/cdoe.12167

15. Vamos CA, Walsh ML, Thompson E, Daley EM, Detman L, DeBate R. Oral-systemic health during pregnancy: exploring prenatal and oral health providers' information, motivation and behavioral skills. Matern Child Health J. 2015;19(6):1263-1275. https://doi.org/10.1007/s10995-014-1632-7

16. Kateeb E, Momany E. Dental caries experience and associated risk indicators among Palestinian pregnant women in the Jerusalem area: a cross-sectional study. BMC Oral Health. 2018;18(1):170. https://doi.org/10.1186/s12903-018-0628-x

17. Sonbul H, Ashi $H$, Aljahdali E, Campus G, Lingström P. The influence of pregnancy on sweet taste perception and plaque acidogenicity. Matern Child Health J. 2017;21(5):1037-1046. https://doi.org/10.1007/s10995-016-2199-2

18. Azofeifa A, Yeung LF, Alverson CJ, Beltrán-Aguilar E. Dental caries and periodontal disease among U.S. pregnant women and nonpregnant women of reproductive age, National Health and Nutrition Examination Survey, 1999-2004. J Public Health Dent. 2016;76(4):320-329. https://doi.org/10.1111/ jphd. 12159

19. Jain K, Kaur H. Prevalence of oral lesions and measurement of salivary $\mathrm{pH}$ in the different trimesters of pregnancy. Singapore Med J. 2015;56(1):53-57. https://doi.org/10.11622/smedj. 2015010

20. Acosta de Camargo MG., Acosta MI. Periodontal disease and pregnancy outcome. are we still in the same place. J Dent Health Oral Disord Ther. 2017;8(2):00280. https://doi. org/10.15406/jdhodt.2017.08.00280

21. Krüger MSM, Casarin RP, Gonçalves LB, Pappen FG, BelloCorrea FO, Romano AR. Periodontal health status and associated factors: findings of a prenatal oral health program in south Brazil. Int J Dent. 2017;2017:3534048. https://doi. org/10.1155/2017/3534048

22. Moimaz SAS, Carmo MP, Zina LG, Saliba NA. Association between the periodontal condition of pregnant women and maternal variables and health assistance. Pesq Bras Odontoped Clin Integr. 2010;10(2):271-278. https://doi. org/10.4034/pboci.v10i2.954

23. Vieira ACF., Alves CMC., Rodrigues VP., Ribeiro CCC., Gomes-Filho IS., Lopes FF. Oral, systemic and socioeconomic factors associated with preterm birth. Women and Birth. 2019;32(1):e12-e16. https://doi.org/10.1016/j.wombi.2018. 02.007

24. Zina LG, Moimaz SAS, Saliba NA, Garbin CAS. Periodontite materna e parto prematuro: aspectos biológicos, epidemiológicos e preventivos. Periodontia. 2005;15(3):10-11.

25. Freire GLM, Ferrari JCL, Percinoto C. Association between maternal breastfeeding and the development of non-nutritive sucking habits. RGO, Rev Gaúch Odontol. 2015;63(2):139-144. https://doi.org/10.1590/1981-863720150002000012295

26. Brasil. Ministério da Saúde. Conselho Nacional de Saúde. $3^{a}$ Conferência Nacional de Saúde Bucal: relatório final: acesso e qualidade superando a exclusão social: relatório final. Brasília: Ministério da Saúde; 2005 [citado 2018 Jul 17]. Disponível em: <http://bvsms.saude.gov.br/bvs/publicacoes/3_conferencia_ nacional_saude_bucal_relatorio_final.pdf>

27. Brasil. Ministério da Saúde. Secretaria de Atenção à Saúde. Departamento de Atenção Básica A saúde bucal no Sistema Único de Saúde. Brasília: Ministério da Saúde; 2018 [citado 2018 Jul 17]. Disponível em: <http://bvsms.saude.gov.br/bvs/ publicacoes/saude_bucal_sistema_unico_saude.pdf >.

28. Brasil. Ministério da Saúde. Secretaria de Atenção à Saúde. Departamento de Atenção Básica. Acolhimento à demanda espontânea. Brasília: Ministério da Saúde; 2011 [citado 2018 Jul 17]. Disponível em: <http://www.saude.sp.gov.br/ resources/humanizacao/biblioteca/documentos-norteadores/ cadernos_de_atencao_basica_-_volume_i.pdf>.

29. Brasil. Ministério da Saúde. Assistência pré-natal: manual técnico. Brasília: Ministério da Saúde; 2000 [citado 2018 Jul 17]. Disponível em: <http://bvsms.saude.gov.br/bvs/ publicacoes/cd04_11.pdf>.

30. Giglio JA, Lanni SM, Laskin DM, Giglio NW. Oral health care for the pregnant patient. J Can Dent Assoc. 2009;75(1):43-48.

31. American Academy on Pediatric Dentistry. Oral health care for the pregnant adolescent. Pediatr Dent. 2016;38(6):221-228.

32. Geisinger ML, Geurs NC, Bain JL, Kaur M, Vassilopoulos PJ, Cliver SP, et al. Oral health education and therapy reduces gingivitis during pregnancy. J Clin Periodontol. 2014;41(2):141-148. https://doi.org/10.1111/jcpe.12188

33. Kelaranta A, Ekholm M, Toroi P, Kortesniemi M. Radiation exposure to foetus and breasts from dental X-ray examinations: effect of lead shields. Dentomaxillofac Radiol. 2016;45(1):20150095. https://doi.org/10.1259/dmfr.20150095

34. European Commission European guidelines on radiation protection in dental radiology: the safe use of radiographs in dental practice. Luxembourg: Publications Office; 2004.

35. Andrade SE, Gurwitz JH, Davis RL, Chan KA, Finkelstein JA, Fortman $\mathrm{K}$, et al. Prescription drug use in pregnancy. Am J Obstet Gynecol. 2004;191(2):398-407. https://doi.org/10.10 16/j.ajog.2004.04.025

36. Nagi R, Yashoda Devi BK, Rakesh N, Reddy SS, Patil DJ. Clinical implications of prescribing nonsteroidal anti-inflammatory drugs in oral health care: a review. Oral Surg Oral Med Oral Pathol Oral Radiol. 2015;119(3):264-271. https://doi.org/10. 1016/j.0000.2014.12.002

37. Hagai A, Diav-Citrin O, Shechtman S, Ornoy A. Pregnancy outcome after in utero exposure to local anesthetics as part of dental treatment: a prospective comparative cohort study. J Am Dent Assoc. 2015;146(8):572-580. https://doi. org/10.1016/j.adaj.2015.04.002

Received on: $27 / 8 / 2018$

Final version resubmitted on: 5/2/2019 Approved on: 16/8/2019 